University of Nebraska - Lincoln

DigitalCommons@University of Nebraska - Lincoln

Agronomy \& Horticulture -- Faculty Publications

Agronomy and Horticulture Department

$6-26-2000$

\title{
Changes in soil microbial community structure with tillage under long-term wheat-fallow management
}

Rhae A. Drijber

University of Nebraska-Lincoln, rdrijber1@unl.edu

John W. Doran

University of Nebraska-Lincoln, jdoran1@unl.edu

Anne M. Parkhurst

University of Nebraska-Lincoln, aparkhurst@unl.edu

D. J. Lyon

Panhandle Research and Extension Center, Scottsbluff, NE, drew.lyon@wsu.edu

Follow this and additional works at: https://digitalcommons.unl.edu/agronomyfacpub

Part of the Plant Sciences Commons

Drijber, Rhae A.; Doran, John W.; Parkhurst, Anne M.; and Lyon, D. J., "Changes in soil microbial community structure with tillage under long-term wheat-fallow management" (2000). Agronomy \& Horticulture -Faculty Publications. 75.

https://digitalcommons.unl.edu/agronomyfacpub/75

This Article is brought to you for free and open access by the Agronomy and Horticulture Department at DigitalCommons@University of Nebraska - Lincoln. It has been accepted for inclusion in Agronomy \& Horticulture -Faculty Publications by an authorized administrator of DigitalCommons@University of Nebraska - Lincoln. 


\title{
Changes in soil microbial community structure with tillage under long-term wheat-fallow management
}

\author{
R.A. Drijber ${ }^{\mathrm{a}, *}$, J.W. Doran ${ }^{\mathrm{b}}$, A.M. Parkhurst ${ }^{\mathrm{c}}$, D.J. Lyon ${ }^{\mathrm{d}}$ \\ ${ }^{a}$ Department of Agronomy, 279 Plant Science, University of Nebraska-Lincoln, Lincoln, NE 68583, USA \\ ${ }^{\mathrm{b}}$ USDA-ARS, $116 \mathrm{Keim}$ Hall, University of Nebraska-Lincoln, Lincoln, NE 68583, USA \\ ${ }^{\mathrm{c}}$ Department of Biometry, 103 Miller Hall, University of Nebraska-Lincoln, Lincoln, NE 68583, USA \\ ${ }^{\mathrm{d}}$ Panhandle Research and Extension Center, 4502 Ave. I, Scottsbluff, NE 69361, USA
}

Received 27 August 1999; received in revised form 13 January 2000; accepted 14 February 2000

\begin{abstract}
Fatty acid methyl esters (FAMEs) were used to 'fingerprint' soil microbial communities that evolved during 25 years of wheat-fallow cropping following native mixed prairie sod at Sidney, Nebraska, USA. Total ester-linked FAMEs (EL-FAMEs) and phospholipid-linked FAMEs (PL-FAMEs) were compared for their ability to discriminate between plots remaining in sod and those cropped to wheat or left fallow under no-till, sub-till or plow management. Cropped plots were higher in microbial biomass than their fallowed counterparts, and did not differ significantly with tillage for the $0-15 \mathrm{~cm}$ depth. Under fallow, microbial biomass was greatest in no-till and least in plow. Both cluster and discriminant analysis of PL- and EL-FAMEs clearly separated the remaining native sod plots from the existing wheat-fallow plots. This separation was particularly pronounced for the EL-FAMEs and was largely driven by high amounts in sod of a single FAME, C16:1(cis11), which has been cited as a biomarker for arbuscular mycorrhizal (AM) fungi. Within wheat-fallow, C16:1(cis11) declined significantly from no-till to plow, which supports the origin of C16:1(cis11) from extraradical mycelium and spores of AM fungi known to be sensitive to soil disturbance. Although discriminant analysis of PL- and EL-FAMEs differentiated wheat and fallow systems by tillage, discrimination among tillage treatments was expressed most strongly during fallow. FAME profiles from fallow plow were most dissimilar from cropped soils which suggests a relationship between tillage management and the long-term resiliency of the microbial community developed under the wheat crop. (C) 2000 Elsevier Science Ltd. All rights reserved.
\end{abstract}

Keywords: Microbial community composition; Tillage; PL-FAMEs; EL-FAMEs; Mycorrhizae

\section{Introduction}

Dryland cropping of winter wheat in a two year rotation with fallow accounts for $42 \%$ of the total 1.3 million dryland cropped hectares in the Panhandle and southwest regions of western Nebraska (Nebraska Agricultural Statistics Service, 1996). In this system, soil water accumulated during fallow is used to support growth of the succeeding wheat crop. Efforts to

\footnotetext{
* Corresponding author. Tel.: +1-402-472-0770; fax: +1-402-4727904.

E-mail address: rdrijber1@unl.edu (R.A. Drijber).
}

increase soil water storage during fallow and reduce soil loss through erosion include adoption of no-tillage (no-till) and reduced tillage (sub-till) practices. Research conducted from 1969 to 1995 on two experimental sites near Sidney, Nebraska, comparing the effects of moldboard plow, sub-till and no-till fallow systems on winter wheat production, found no significant yield benefit with no-till despite increased soil water storage in the soil profile at time of planting (Lyon et al., 1998). Heavy infestation with downy brome (Bromus tectorum L.) of no-till and sub-till plots since 1983 has undoubtedly contributed to decreased yields in no-till, despite the additional water stored in the soil profile (Lyon et al., 1998). Adequate 
weed control through tillage has led to limited adoption of no-till winter wheat-fallow systems in the Central Great Plains.

Although the economic sustainability of no-till winter wheat-fallow in the Central Great Plains is in question, no-till preserves the soil resource better than either plow or sub-till management. Several studies have detailed the physical, chemical and biological changes in the soil profile at the above research sites to understand fully the limitations to winter wheat yields in wheat-fallow systems. Adoption of no-till has redistributed soil carbon and microbial biomass towards the soil surface (Doran, 1987), increased potentially mineralizable $\mathrm{N}$, while initially reducing soil $\mathrm{NO}_{3}-\mathrm{N}$ levels (Broder et al., 1984), increased potential enzyme activities, such as dehydrogenase and phosphatase (Doran and Linn, 1994), reduced emissions of greenhouse gases (Kessavalou et al., 1998) and lowered surface soil bulk density (Mielke and Wilhelm, 1998). These changes are reflected in declining ratios of selected culturable populations between no-till and plowed soils with soil depth (Doran, 1980).

Concern over global warming has prompted research on carbon sequestration in agroecosystems and the importance of tillage intensity to soil structure and soil organic matter dynamics (Beare et al., 1994; Cambardella and Elliott, 1992; Huggins et al., 1998; Paustian et al., 1995; Peterson et al., 1998). Cultivation of native prairie in the Central Great Plains leads to a rapid decline in soil carbon, particularly surface soil carbon (Doran et al., 1998; Follett et al., 1997). At Sidney, losses of soil carbon with cultivation have been attributed to erosion (O'Halloran et al., 1987), reduced C inputs during fallow (Doran et al., 1998) and loss of particulate organic matter associated with macroaggregates (Cambardella and Elliott, 1993).

To date, biological changes brought about by cultivation of native prairie and wheat-fallow cropping at the long-term tillage site near Sidney, NE include losses in total biomass (Doran et al., 1998), reduced fungal to bacterial biomass (Frey et al., 1999) and shifts in selected culturable populations (Broder et al., 1984). Although the above studies provide evidence for gross microbial responses to soil management, details are lacking on specific responses of the in situ microbial community, beyond which it is known for culturable organisms. With newer biochemical (lipids) and molecular (DNA/RNA) tools we are now better equipped to identify microbial community responses to soil management. In this study, we used fatty acid methyl esters (FAMEs) to 'fingerprint' microbial communities that have evolved during 25 years of wheatfallow cropping following native mixed prairie sod. Total ester-linked FAMEs (EL-FAMEs) and phospholipid-linked FAMEs (PL-FAMEs) were compared for their ability to discriminate among plots remaining in sod and those cropped to wheat or left fallow under no-till, sub-till or plow management.

\section{Materials and methods}

Soil was collected on August 31, 1995, four weeks after wheat harvest, from research plots established in 1969 on native mixed prairie sod and seeded to wheat in 1970. The soil, a Duroc loam (fine-silty, mixed, mesic Pachic Haplustoll), is located at the High Plains Agricultural Research Laboratory at Sidney, Nebraska $\left(41^{\circ} 14^{\prime} \mathrm{N}, 103^{\circ} 00^{\prime} \mathrm{W} ; 1311 \mathrm{~m}\right.$ above sea level). Six soil cores $(15 \times 1.9 \mathrm{~cm}$, diameter $)$ were composited from each plot $(45.5 \times 8.5 \mathrm{~m})$ organized into two blocks: one seeded to winter wheat (W), the other left fallow (F) each year. Each block of 12 plots contained three replicate plots of three tillage treatments: plow $(\mathrm{P})$, sub-till (ST) and no-till (NT); and a control 'sod' plot (native mixed prairie grasses). Twenty-four composite soil samples were collected from the site. Sampled plots have never received inorganic fertilizer nitrogen. For the plow treatments, a moldboard plow was used to till the soil to a depth of $10-15 \mathrm{~cm}$ in the spring, followed by three to five operations with a field cultivator, disk or rotary rodweeder. Sub-till operations were performed with $0.9 \mathrm{~m}$ or $1.5 \mathrm{~m}$ sweeps at a depth of $10-15 \mathrm{~cm}$, two to four times a year followed by one or two passes with the rotary rodweeder. Seeding was the only operation in NT that caused soil disruption and herbicides were used to control weeds. Sod was burned in 1980 and 1994 to encourage growth of warm-season grasses. Further management history is detailed elsewhere (Fenster and Peterson, 1979; Lyon et al., 1998).

After sampling, soil was transported in a cooler to the laboratory and stored at $5^{\circ} \mathrm{C}$ for less than $24 \mathrm{~h}$, before being passed through a $2 \mathrm{~mm}$ sieve to remove visible organic residues. After thoroughly mixing, subsamples were taken for water content and for immediate extraction of lipids. Bulk density at the time of sampling was estimated from the mass of oven-dry soil collected from the six cores.

\subsection{Lipid extraction and fractionation}

A modified Bligh and Dyer procedure as described in Drijber and McGill (1994) extracted lipids from 10 g soil. The lipid extracts were stored at $-22^{\circ} \mathrm{C}$. All solvents were of high purity, glass distilled and filtered (Sigma, HPLC grade). Chloroform was stabilized with amylenes.

Microbial biomass was determined as extractable lipid phosphorus. Phosphate released through perchloric acid digestion was determined by the method of Bartlett as described by Kates (1986). Microbial com- 
munity structure was determined from PL-FAMEs and EL-FAMEs. Phospholipids were separated from the lipid extracts by column chromatography with silica gel as the adsorbent. A $500 \mu \mathrm{l}$ aliquot of lipid extract was evaporated under $\mathrm{N}_{2}$ and redissolved in a small volume of chloroform then applied to the top of a $10 \times 30 \mathrm{~mm}$ chromatography column containing 1.5 $\mathrm{g}$ of silica gel (Davisil, 100-200 mesh, Aldrich) in chloroform. Neutral lipids and glycolipids were eluted from the silica gel with $10 \mathrm{ml}$ chloroform and $10 \mathrm{ml}$ acetone, respectively. Polar lipids (mainly phospholipids) were then eluted with $10 \mathrm{ml}$ methanol into a 15 ml Pyrex test tube with a Teflon-lined screw cap. Methanol was evaporated under $\mathrm{N}_{2}$ at $37^{\circ} \mathrm{C}$.

The phospholipids were hydrolyzed and the resulting fatty acids methylated by mild alkaline hydrolysis (White et al., 1979). This procedure does not methylate free fatty acids, only ester-linked fatty acids (Grogan and Cronan, 1997; Kates, 1986). The resulting PLFAMEs were partitioned into hexane, the solvent removed under $\mathrm{N}_{2}$ and the PL-FAMEs redissolved into $100 \mu \mathrm{l}$ hexane:chloroform $(4: 1 \mathrm{v} / \mathrm{v})$ containing the internal standard methyl-nonadecanoate. EL-FAMEs were released through direct saponification of the lipid extract without prior separation into neutral, glycoand phospholipid classes and processed as above.

\subsection{Quantification and identification of FAMEs}

EL-FAMEs and PL-FAMEs were separated by capillary gas chromatography on a Hewlett Packard 5890 Series II gas chromatograph in split mode (20:1) housing a cross-linked polydimethylsiloxane capillary column $(30 \mathrm{~m}, 0.25 \mathrm{~mm}$ I.D., $0.1 \mu \mathrm{m}$ film thickness, HP-1 Hewlett Packard). Helium was used as the carrier gas. The oven temperature was held at $100^{\circ} \mathrm{C}$ for 1 min then increased at $2.5^{\circ} \mathrm{C} \mathrm{min}{ }^{-1}$ to $225^{\circ} \mathrm{C}$. The injector and flame ionization detector temperatures were $250^{\circ} \mathrm{C}$ and $280^{\circ} \mathrm{C}$, respectively. An internal standard, methyl-nonadecanoate $(0.4 \mu \mathrm{g} \mathrm{C19:0/ \mu l)}$ was added to the FAME extract to ensure reproducibility in the amount of lipid entering the capillary column. Identification of the FAMEs was by comparison of retention time and equivalent chain length with known standards (Bacterial Acid Methyl Esters CP Mix, Supelco USA) and confirmed by gas chromatography mass spectrometry (GC-MS). Unsaturated and substituted FAMEs were identified by GC-MS as dimethyldisulfide (Nichols et al., 1986a) and dimethyloxazoline derivatives ( $\mathrm{Yu}$ et al., 1989).

\subsection{FAME nomenclature}

Fatty acids were designated as the total number of carbon atoms followed by a colon, the number of double bonds followed by the position of the double bond from the carboxyl end of the molecule and its cis or trans configuration in brackets. For example, 18:2(cis 9,12) denotes linoleic acid, which is an 18 carbon chain with two double bonds at the number nine and 12 carbon atoms, with cis configurations. The prefixes $a$ and $i$ indicate antieso and iso branching, respectively, $b r$ indicates an unknown branch position, $10 \mathrm{Me}$ indicates a methyl branch on the 10th carbon atom from the carboxyl end of the molecule, and $c y$ $(9,10)$ refers to cyclopropane ring between the 9th and 10 th carbon atom.

\subsection{Data analysis}

Measured soil properties were analyzed by analysis of variance and then ranked using Tukey's HSD test (Statistica, 1995). Individual FAMEs were reported as ratios of peak area to methyl-hexadecanoate (C16:0). FAME ratios less than 0.02 and FAMEs occurring in fewer than five samples with no apparent treatment pattern were omitted from the data set. FAMEs with retention times less than $\mathrm{C} 14: 0$ and greater than $\mathrm{C} 20: 0$, which were few in number, were also deleted from the data set. Stepwise and canonical discriminant analysis (SAS, 1989) and cluster analysis (Statistica, 1995) were performed on the remaining 29 FAME ratios listed in Fig. 1.

\section{Results}

\subsection{Soil conditions at time of sampling}

At the time of sampling, all fields were well below the 60 percent water-filled pore space (\%WFPS) required for optimum aerobic biological activity (Table 1). The sod plots were especially dry and difficult to penetrate with the soil corer. Conversely, the plow plots were loose, and so, bulk density may have been underestimated. Additional water conservation by no-till during fallow was not evident at this time as indicated by the low \%WFPS of surface soil. The plow and sub-till cropped soils were also lower in $\%$ WFPS compared to the fallowed plots, which is not surprising for post harvest. The sod pots were extremely dry and contained less than half the pore water found in the cropped or fallowed plots. Despite high penetration resistance, the sod plots had the lowest bulk density (Table 1). Bulk densities among the cropped soils did not differ significantly. Reconsolidation of the plow and sub-till plots was evident in the fallow year.

\subsection{Microbial biomass and FAMEs}

Microbial biomass, measured as extractable lipid P, 


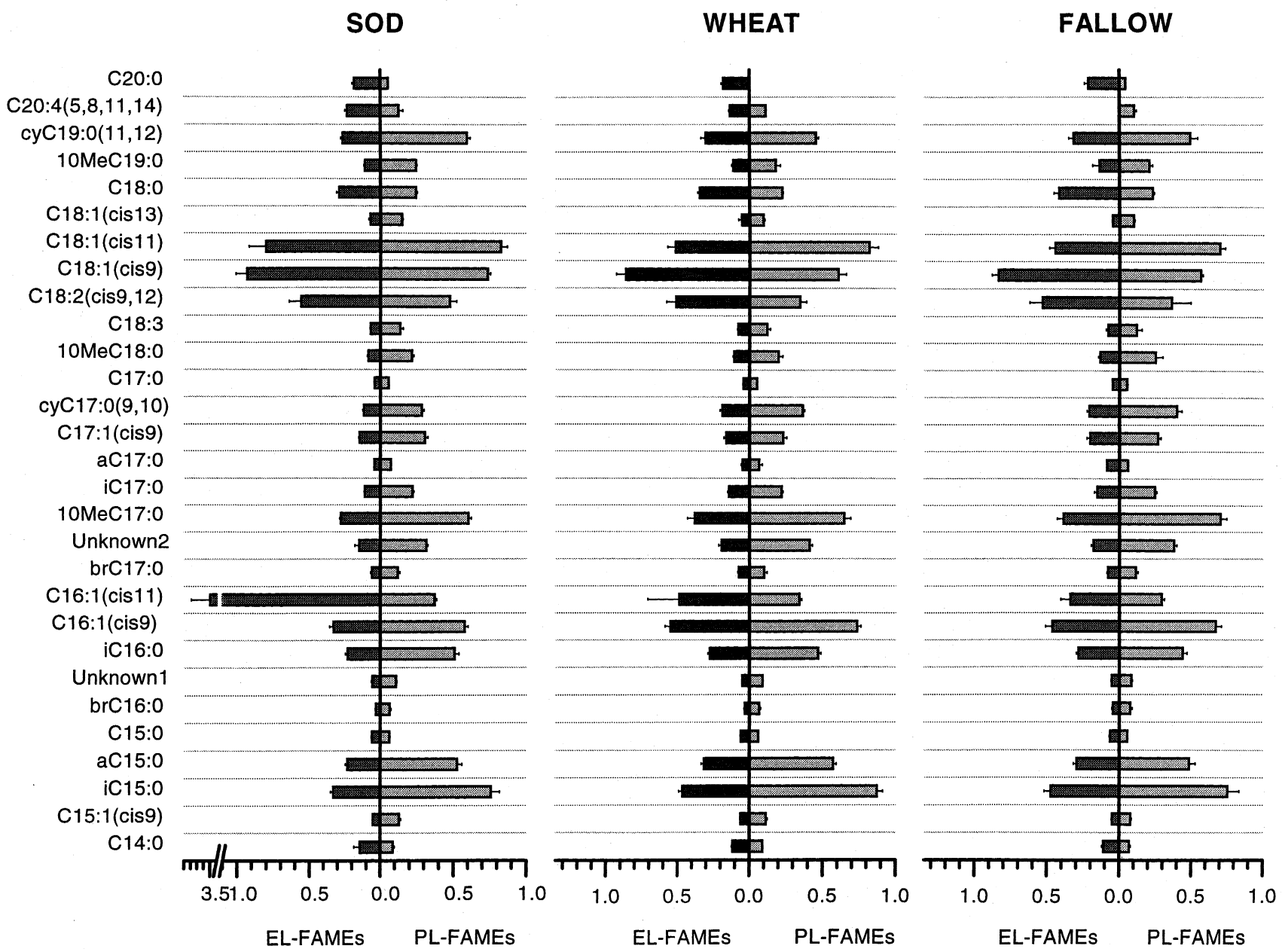

Ratio of FAME Peak Area to Peak Area of C16:0

Fig. 1. Mean and standard deviations of ratios of FAME peak area to peak area of C16:0, averaged across tillage treatments. PL-FAMEs $=$ phospholipid-linked FAMEs; EL-FAMEs = ester-linked FAMEs. Sod $(n=6)$, Wheat $(n=9)$, Fallow $(n=9$ for EL-FAMEs; $n=8$ for PLFAMEs).

Table 1

Soil characteristics of the $0-15 \mathrm{~cm}$ depth at time of sampling on August 31, 1995

\begin{tabular}{|c|c|c|c|c|}
\hline Tillage and crop cycle & Bulk density $\left(\mathrm{Mg} / \mathrm{m}^{3}\right)$ & WFPS $^{\mathrm{a}}(\%)$ & Biomass as lipid-phosphorus $\left(\mathrm{kg} \mathrm{P} \mathrm{ha}^{-1}\right)$ & 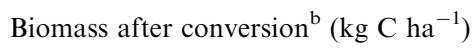 \\
\hline \multicolumn{5}{|l|}{ Cropped } \\
\hline Plow & $1.21^{\mathrm{c}} \mathrm{b}$ & $36 \mathrm{~b}$ & $2.08 \mathrm{a}$ & 606 a \\
\hline Sub-till & $1.21 \mathrm{~b}$ & $38 \mathrm{bc}$ & $2.54 \mathrm{ab}$ & $739 a b$ \\
\hline No-till & $1.19 \mathrm{~b}$ & $44 \mathrm{c}$ & $2.58 \mathrm{ab}$ & $749 a b$ \\
\hline Sod & $0.93 \mathrm{a}$ & $16 \mathrm{a}$ & $2.72 \mathrm{~b}$ & $792 \mathrm{~b}$ \\
\hline \multicolumn{5}{|l|}{ Fallow } \\
\hline Plow & $1.40 \mathrm{c}$ & $47 \mathrm{~b}$ & $1.53 \mathrm{a}$ & 446 a \\
\hline Sub-till & $1.40 \mathrm{c}$ & $44 \mathrm{~b}$ & $1.69 \mathrm{ab}$ & $491 \mathrm{ab}$ \\
\hline No-till & $1.24 \mathrm{~b}$ & $41 \mathrm{~b}$ & $2.11 \mathrm{bc}$ & $614 \mathrm{bc}$ \\
\hline Sod & $1.05 \mathrm{a}$ & $16 \mathrm{a}$ & $2.60 \mathrm{c}$ & $755 \mathrm{c}$ \\
\hline
\end{tabular}

${ }^{\mathrm{a}}$ WFPS $=$ water-filled pore space, $\mathrm{cm}^{3} \mathrm{H}_{2} \mathrm{O} / \mathrm{cm}^{3}$ pores.

${ }^{\mathrm{b}}$ Conversion factors: $50 \mu \mathrm{mol} \mathrm{P} / \mathrm{g}$ dry cells $=1.55 \mathrm{mg} \mathrm{P} / \mathrm{g}$ dry cells (White et al., 1979); $0.45 \mathrm{~g} \mathrm{C} / \mathrm{g}$ dry cells (Paul and Clark, 1989).

${ }^{\mathrm{c}}$ Treatment means $(n=3)$ within crop cycle followed by the same letter do not differ significantly at $P<0.05$ by Tukey's HSD Test. 
was highest in the sod plots, while recently cropped soils were higher in microbial biomass than their fallowed counterparts (Table 1). Means of 29 FAME ratios, averaged across tillage treatments, are represented in Fig. 1. Traditionally, FAME data are analyzed as mol\% of total FAMEs (Bååth et al., 1995; Frostegård et al., 1993; Petersen and Klug, 1994; Petersen et al., 1997; Reichardt et al., 1997; Wander et al., 1995; Zogg et al., 1997). Alternatively, FAMEs can be normalized to C16:0, often the most abundant FAME in the sample, which correlates well with total biomass (Zelles et al., 1992). We chose the latter method to avoid having a change in the amount of a single FAME affecting the ratios of other FAMEs in the profile. PL-FAMEs were dominated by $\mathrm{C} 16: 0$ as indicated by ratios of FAME peak area relative to C16:0 all being less than one. Other abundant PLFAMEs with ratios $>0.3$ included several monounsaturated [C18:1(cis11), C18:1(cis9), C16:1(cis9), $\mathrm{C} 16: 1(\operatorname{cis} 11)]$ and branched $[i \mathrm{C} 15: 0, i \mathrm{C} 16: 0, a \mathrm{C} 15: 0$,
10Me C17:0] FAMEs. Also prevalent were cy19:0(11,12) and C18:2(cis 9,12). These FAMEs were also abundant in the EL-FAMEs of the wheat and fallow plots; albeit with differing mean ratios. ELFAMEs of the sod plots were dominated by C16:1(cis11), which was derived largely from the acetone eluate during silica gel fractionation (data not shown).

To compare differences in FAME profiles between PL-FAMEs, and EL-FAMEs as well as among cropping cycles and tillage treatments the data were analyzed by cluster analysis (Fig. 2). Unweighted pairgroup averaging of 29 FAME ratios grouped the soils into three main clusters: PL-FAME profiles, ELFAME profiles and EL-FAME profiles from sod plots. Distance between clusters was calculated as the average euclidean distance between all pairs of FAMEs in two different clusters. Within the PLFAMES, the sod plots clustered separately from the wheat-fallow plots. The wheat plots formed one cluster

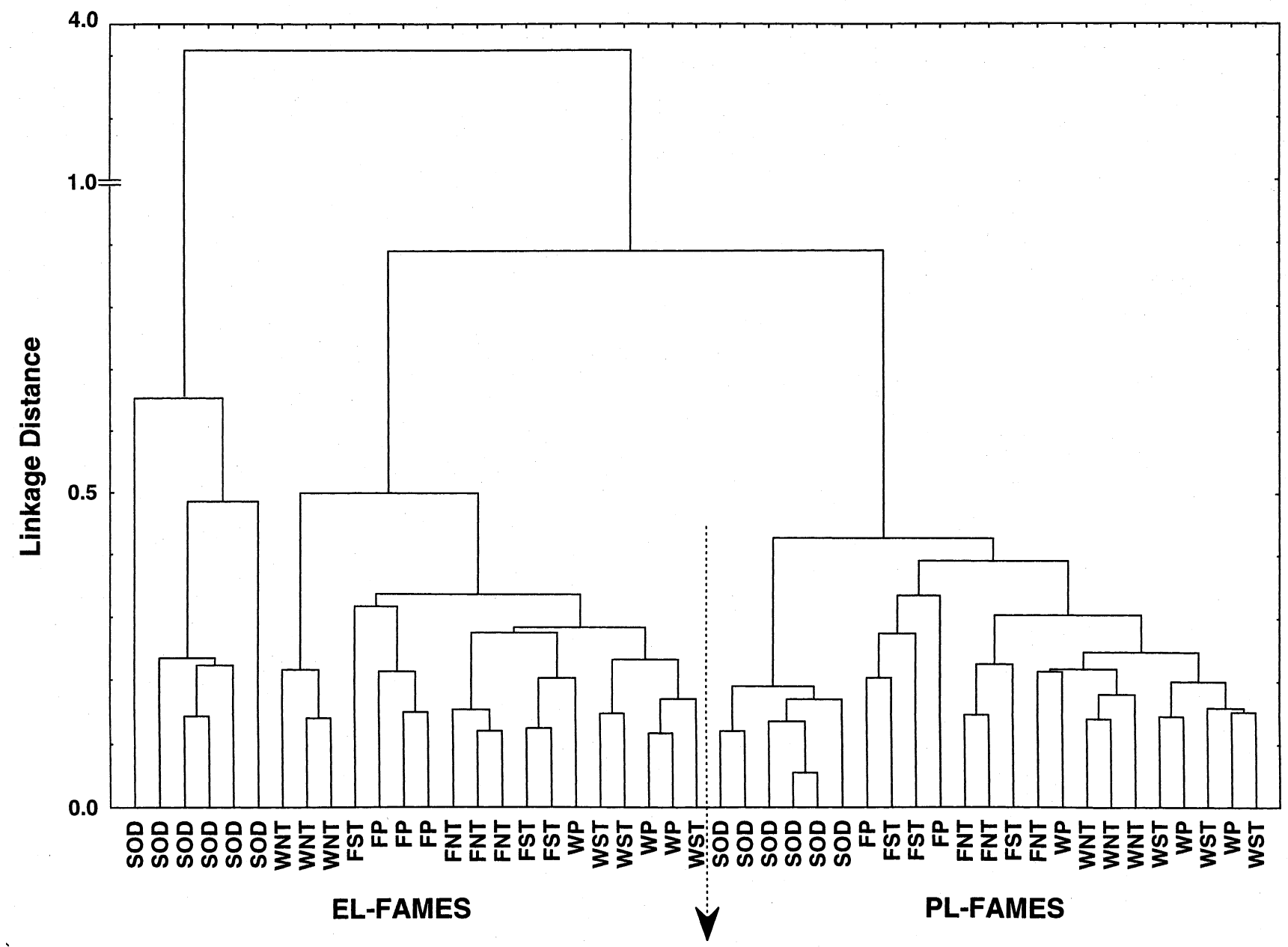

Fig. 2. Cluster analysis of 29 FAMEs by unweighted pair-group average of euclidean distance (Statistica, 1995). PL-FAMEs = phospholipidlinked FAMEs; EL-FAMEs = ester-linked FAMEs. FP = fallow, plow; FST = fallow, sub-till; FNT = fallow, no-till; WP = wheat, plow; WST $=$ wheat, sub-till; WNT $=$ wheat, no-till. 
with the inclusion of one fallow no-till (FNT). Although patterns were evident for the fallow plots based on tillage, significant chaining was evident making interpretation less clear. Cluster patterns among the tillage-crop cycles were more distinct for the ELFAMEs. FAME profiles after wheat in no-till (WNT) formed a distant (0.5) and unique cluster, as did fallow plow (FP) [with the inclusion of one fallow sub-till (FST)]. Within the remaining cluster, FNT was tightly clustered and distant from the remaining FST, wheat sub-till (WST) and wheat plow (WP) plots.

To uncover specific FAMEs responsible for treatment discrimination we used discriminant analysis (Proc Stepdisc; SAS, 1989) with the stepwise selection method to enter or remove FAMEs from the model. The discriminant model was then evaluated using a canonical discriminant analysis (Proc Candisc; SAS, 1989). To explore the better relationships among treatments and to detect significant separation, a matrix of squared distances between treatment means adjusted for their covariances (i.e. Mahalanobis distances) and the associated probability of significance was examined. The number of dimensions needed to distinguish among the treatments was identified by the number of significant canonical discriminant functions. Each function is a linear combination of FAME variables. The first function has the most power to discriminate among the treatments. The correlations between the function and the FAMEs help to identify the FAMEs which are most responsible for treatment discrimination. A discriminant score is computed for each of the 24 plots for each significant discriminant functions. Graphs of the discriminant scores show how the treatments cluster. Graphs of the correlations show how the FAME variables cluster on the discriminant functions.
Stepwise discriminant analysis was performed on 29 PL-FAME ratios from 23 samples, one FP sample being lost during sample analysis. Eleven PL-FAMEs were identified by the analysis as being significant for the discrimination model. The $p$-values for the Mahalanobis distances (Table 2) show significant separation between all treatment means except WP and WST.

The canonical discriminant analysis identified four significant discriminant functions $(p<0.01)$. The discriminant functions associated with the first and second eigenvalues, DA1 and DA2, accounted for $78.9 \%$ and $18.0 \%$ of the variance for a total explained variance of $96.9 \%$. Discriminant scores for DA1 and DA2 are plotted in Fig. 3a, while correlations of individual FAMEs with the first and second discriminant functions are plotted in Fig. $3 b$.

Two discriminant functions containing 11 variables were adequate to separate all seven treatments, with the exception of WP and WST. On DA1, sod plots were significantly distant from cropped soils $(p<0.0001)$. PL-FAME ratios positively correlated with DA1 included C18:1(cis13), C18:1(cis9), unknown FAME (Unk1), C16:1(cis11), C17:1(cis9) and $10 \mathrm{Me}$ C19:0, which were enriched in sod compared to wheatfallow. Large negative correlations were found for cyC17:0 and C16:1(cis9). The second discriminant function, DA 2, mainly separated FP from the remaining cropped soils $(p<0.01)$ due to smaller ratios of $a \mathrm{C} 15: 0$ and $\mathrm{C} 16: 1\left({ }^{2} i s 9\right)$ and the absence of $\mathrm{C} 15: 0$ from these samples.

Stepwise discriminant analysis was performed on 29 EL-FAME ratios from 24 samples. Thirteen ELFAMEs were identified by the analysis as being significant for the discrimination model. The $p$-values for the Mahalanobis distances (Table 3) show significant separation between treatment means for sod and cropped

Table 2

Pairwise squared Mahalanobis distances for PL-FAMEs between treatments

\begin{tabular}{|c|c|c|c|c|c|c|c|}
\hline Treatment & WP & WST & WNT & FP & FST & FNT & SOD \\
\hline & \multicolumn{7}{|c|}{ Squared Mahalanobis distance/(probability $>$ Mahalanobis distance) } \\
\hline $\mathrm{WP}^{\mathrm{a}}$ & $\begin{array}{l}0 \\
(1.0000)\end{array}$ & $\begin{array}{l}43 \\
(0.1724)\end{array}$ & $\begin{array}{l}282 \\
(0.0019)\end{array}$ & $\begin{array}{l}2674 \\
(0.0001)\end{array}$ & $\begin{array}{l}350 \\
(0.001)\end{array}$ & $\begin{array}{l}219 \\
(0.0038)\end{array}$ & $\begin{array}{l}2894 \\
(0.0001)\end{array}$ \\
\hline WST & $\begin{array}{l}43 \\
(0.1724)\end{array}$ & $\begin{array}{l}0 \\
(1.0000)\end{array}$ & $\begin{array}{l}399 \\
(0.0007)\end{array}$ & $\begin{array}{l}2761 \\
(0.0001)\end{array}$ & $\begin{array}{l}493 \\
(0.0004)\end{array}$ & $\begin{array}{l}240 \\
(0.003)\end{array}$ & $\begin{array}{l}2372 \\
(0.0001)\end{array}$ \\
\hline WNT & $\begin{array}{l}282 \\
(0.0019)\end{array}$ & $\begin{array}{l}399 \\
(0.0007)\end{array}$ & $\begin{array}{l}0 \\
(1.0000)\end{array}$ & $\begin{array}{l}2063 \\
(0.0001)\end{array}$ & $\begin{array}{l}90 \\
(0.0364)\end{array}$ & $\begin{array}{l}119 \\
(0.0189)\end{array}$ & $\begin{array}{l}4152 \\
(0.0001)\end{array}$ \\
\hline FP & $\begin{array}{l}2674 \\
(0.0001)\end{array}$ & $\begin{array}{l}2761 \\
(0.0001)\end{array}$ & $\begin{array}{l}2063 \\
(0.0001)\end{array}$ & $\begin{array}{l}0 \\
(1.0000)\end{array}$ & $\begin{array}{l}2372 \\
(0.0001)\end{array}$ & $\begin{array}{l}2225 \\
(0.0001)\end{array}$ & $\begin{array}{l}6577 \\
(0.0001)\end{array}$ \\
\hline FST & $\begin{array}{l}350 \\
(0.001)\end{array}$ & $\begin{array}{l}493 \\
(0.0004)\end{array}$ & $\begin{array}{l}90 \\
(0.0364)\end{array}$ & $\begin{array}{l}2372 \\
(0.0001)\end{array}$ & $\begin{array}{l}0 \\
(1.0000)\end{array}$ & $\begin{array}{l}270 \\
(0.0022)\end{array}$ & $\begin{array}{l}4636 \\
(0.0001)\end{array}$ \\
\hline FNT & $\begin{array}{l}219 \\
(0.0038)\end{array}$ & $\begin{array}{l}240 \\
(0.003)\end{array}$ & $\begin{array}{l}119 \\
(0.0189)\end{array}$ & $\begin{array}{l}2225 \\
(0.0001)\end{array}$ & $\begin{array}{l}270 \\
(0.0022)\end{array}$ & $\begin{array}{l}0 \\
(1.0000)\end{array}$ & $\begin{array}{l}3039 \\
(0.0001)\end{array}$ \\
\hline SOD & $\begin{array}{l}2894 \\
(0.0001)\end{array}$ & $\begin{array}{l}2372 \\
(0.0001)\end{array}$ & $\begin{array}{l}4152 \\
(0.0001)\end{array}$ & $\begin{array}{l}6577 \\
(0.0001)\end{array}$ & $\begin{array}{l}4636 \\
(0.0001)\end{array}$ & $\begin{array}{l}3039 \\
(0.0001)\end{array}$ & $\begin{array}{l}0 \\
(1.0000)\end{array}$ \\
\hline
\end{tabular}

${ }^{\mathrm{a}} \mathrm{WP}=$ wheat, plow; WST $=$ wheat, sub-till; WNT $=$ wheat, no-till; FP $=$ fallow, plow; FST $=$ fallow, sub-till; FNT $=$ fallow, no-till. 
a.
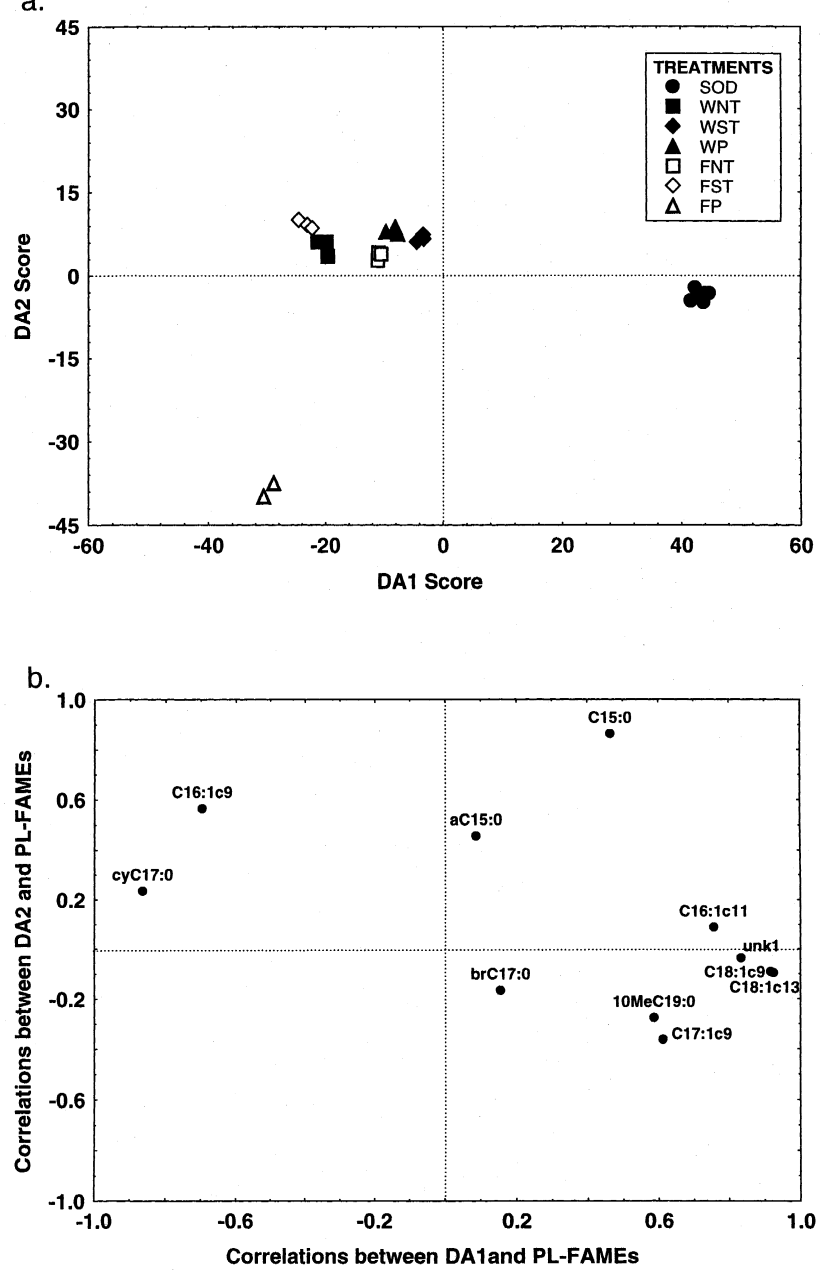

Fig. 3. Discriminant scores of treatments for (a) and correlations of PL-FAMEs with (b) the first two significant discriminant functions, DA1 and DA2. FP = fallow, plow; FST = fallow, sub-till; FNT = fallow, no-till; WP $=$ wheat, plow; WST $=$ wheat, sub-till; WNT $=$ wheat, no-till. Note: one FP sample lost during sample handling.
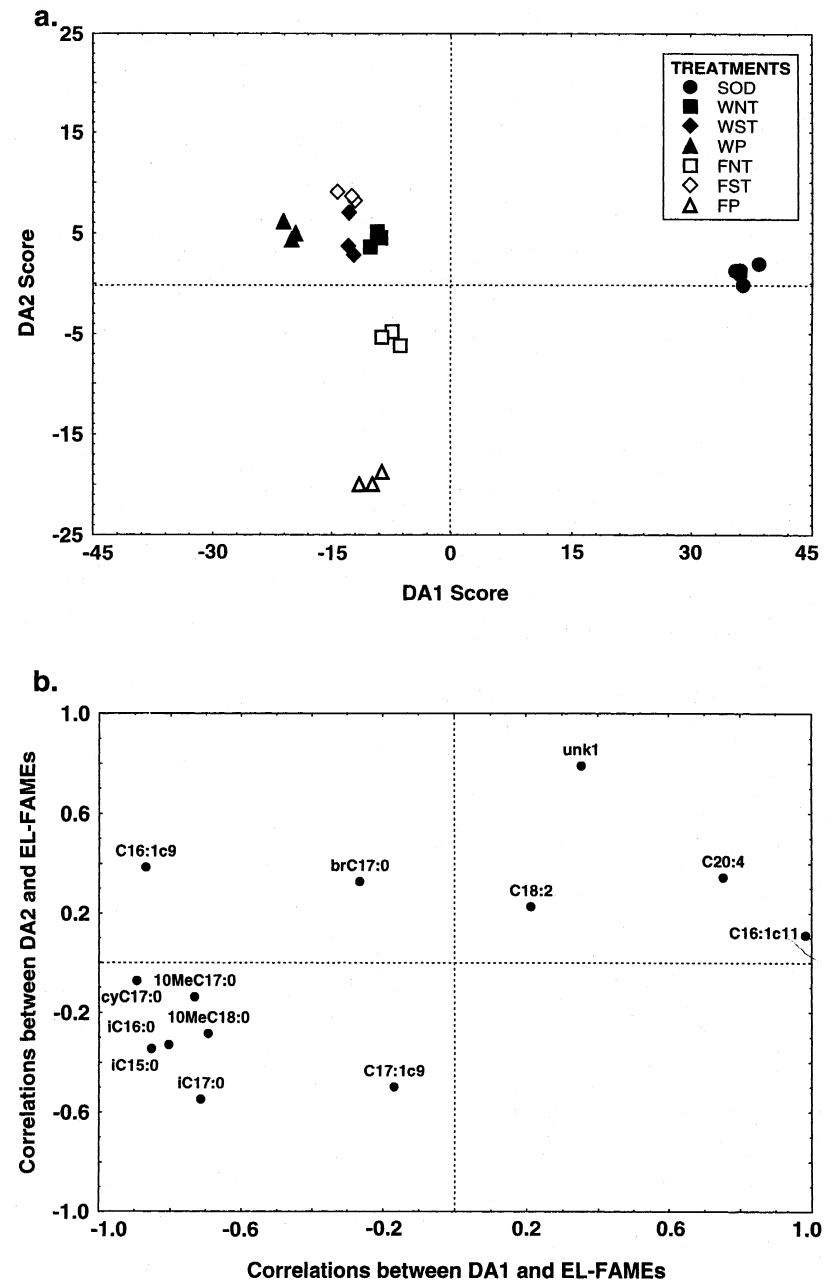

Fig. 4. Discriminant scores of treatments for (a) and correlations EL-FAMEs with (b) the first two significant discriminant functions, DA1 and DA2. FP $=$ fallow, plow; FST $=$ fallow, sub-till; FNT $=$ fallow, no-till; WP $=$ wheat, plow; WST $=$ wheat, sub-till; WNT $=$ wheat, no-till.

Table 3

Pairwise squared Mahalanobis distances for EL-FAMEs between treatments

\begin{tabular}{|c|c|c|c|c|c|c|c|}
\hline Treatment & WP & WST & WNT & FP & FST & FNT & SOD \\
\hline & \multicolumn{7}{|c|}{ Squared Mahalanobis distance/(Probability $>$ Mahalanobis distance) } \\
\hline$W P^{a}$ & $\begin{array}{l}0 \\
(1.0000)\end{array}$ & $\begin{array}{l}99 \\
(0.0952)\end{array}$ & $\begin{array}{l}256 \\
(0.0132)\end{array}$ & $\begin{array}{l}775 \\
(0.0010)\end{array}$ & $\begin{array}{l}205 \\
(0.0215)\end{array}$ & $\begin{array}{l}381 \\
(0.0053)\end{array}$ & $\begin{array}{l}3264 \\
(0.0001)\end{array}$ \\
\hline WST & $\begin{array}{l}99 \\
(0.0952)\end{array}$ & $\begin{array}{l}0 \\
(1.0000)\end{array}$ & $\begin{array}{l}69 \\
(0.1805)\end{array}$ & $\begin{array}{l}602 \\
(0.0018)\end{array}$ & $\begin{array}{l}101 \\
(0.0914)\end{array}$ & $\begin{array}{l}229 \\
(0.0169)\end{array}$ & $\begin{array}{l}2429 \\
(0.0001)\end{array}$ \\
\hline WNT & $\begin{array}{l}256 \\
(0.0132)\end{array}$ & $\begin{array}{l}69 \\
(0.1805)\end{array}$ & $\begin{array}{l}0 \\
(1.0000)\end{array}$ & $\begin{array}{l}628 \\
(0.0016)\end{array}$ & $\begin{array}{l}159 \\
(0.0369)\end{array}$ & $\begin{array}{l}261 \\
(0.0127)\end{array}$ & $\begin{array}{l}2170 \\
(0.0001)\end{array}$ \\
\hline FP & $\begin{array}{l}775 \\
(0.0010)\end{array}$ & $\begin{array}{l}602 \\
(0.0018)\end{array}$ & $\begin{array}{l}628 \\
(0.0016)\end{array}$ & $\begin{array}{l}0 \\
(1.0000)\end{array}$ & $\begin{array}{l}844 \\
(0.0008)\end{array}$ & $\begin{array}{l}338 \\
(0.0070)\end{array}$ & $\begin{array}{l}2594 \\
(0.0001)\end{array}$ \\
\hline FST & $\begin{array}{l}205 \\
(0.0215)\end{array}$ & $\begin{array}{l}101 \\
(0.0914)\end{array}$ & $\begin{array}{l}159 \\
(0.0369)\end{array}$ & $\begin{array}{l}844 \\
(0.0008)\end{array}$ & $\begin{array}{l}0 \\
(1.0000)\end{array}$ & $\begin{array}{l}342 \\
(0.0068)\end{array}$ & $\begin{array}{l}2545 \\
(0.0001)\end{array}$ \\
\hline FNT & $\begin{array}{l}381 \\
(0.0053)\end{array}$ & $\begin{array}{l}229 \\
(0.0169)\end{array}$ & $\begin{array}{l}261 \\
(0.0127)\end{array}$ & $\begin{array}{l}338 \\
(0.0070)\end{array}$ & $\begin{array}{l}342 \\
(0.0068)\end{array}$ & $\begin{array}{l}0 \\
(1.0000)\end{array}$ & $\begin{array}{l}2043 \\
(0.0001)\end{array}$ \\
\hline SOD & $\begin{array}{l}3264 \\
(0.0001)\end{array}$ & $\begin{array}{l}2429 \\
(0.0001)\end{array}$ & $\begin{array}{l}2170 \\
(0.0001)\end{array}$ & $\begin{array}{l}2594 \\
(0.0001)\end{array}$ & $\begin{array}{l}2545 \\
(0.0001)\end{array}$ & $\begin{array}{l}2043 \\
(0.0001)\end{array}$ & $\begin{array}{l}0 \\
(1.0000)\end{array}$ \\
\hline
\end{tabular}

\footnotetext{
${ }^{\mathrm{a}} \mathrm{WP}=$ wheat, plow; WST $=$ wheat, sub-till; WNT $=$ wheat, no-till; FP $=$ fallow, plow; FST $=$ fallow, sub-till; FNT $=$ fallow, no-till.
} 
soils $(p<0.0001)$. All cropped soils were significantly different $(p<0.05)$ from each other except for WST, which was not different from WP, WNT or FST.

The canonical discriminant analysis identified five significant discriminant functions $(p<0.01)$. The discriminant functions associated with the first and second eigenvalues, DA1 and DA2, accounted for $82.3 \%$ and $12.5 \%$ of the variance for a total explained variance of $94.8 \%$. Discriminant scores for DA1 and DA2 are plotted in Fig. 4a, while correlations of individual FAMEs with the first and second discriminant functions are plotted in Fig. 4b.

Two discriminant functions containing 13 variables were adequate to separate all treatments with the exception of WST, which was not different from WP, WNT or FST. Once again, on DA1, sod plots were distant from cropped soils with WP receiving the lowest score. EL-FAME ratios positively correlated with DA1 included C16:1(cis11) and C20:4(5,8,11,14). Large negative correlations were found for isobranched (iC15:0, iC16:0, iC17:0), 10-methyl branched (10 Me C17:0, 10 Me C18:0), C16:1(cis9) and cyC17:0(9,10) FAMEs. DA2 was most instrumental in discriminating among the tillage treatments during fallow with $i \mathrm{C} 17: 0, \mathrm{C} 17: 1(c i s 9)$ and an unknown FAME (Unk1) being most important. FP plots received the lowest scores indicating higher ratios for $i \mathrm{C} 17: 0$ and C17:1(cis9) and the absence of Unk1.

The relationship of selected PL- and EL-FAMEs to crop and tillage management is presented in Table 4.

\section{Discussion}

Cultivation of native sod followed by 25 years of wheat-fallow cropping has produced quantitative changes in the amounts and distribution of soil mi- crobial biomass. These changes where observed within the first 10 years of the study as reported by Doran (1987). Microbial biomass, measured as extractable lipid phosphorus, followed previous trends established for this field site by chloroform fumigation incubation (Doran et al., 1998). Cropped plots were higher in microbial biomass than their fallowed counterparts, and did not differ significantly with tillage for the $0-15 \mathrm{~cm}$ depth. Under fallow, microbial biomass was greatest in no-till and least in plow. Microbial biomass in sod was not significantly greater than that of no-till. Despite similar rankings for $\mathrm{kg}$ microbial biomass $\mathrm{C} \mathrm{ha} \mathrm{ha}^{-1}$ among treatments, biomass by chloroform fumigation was two to three times greater that that calculated from lipid phosphorus. This may reflect different sampling times (spring vs. fall), but more likely reflects fundamental differences between the methods: chloroform fumigation is based on a physiological response, while lipid phosphorus relies heavily on extraction efficiency. Both methods are calibrated against other measures of biomass, such as microscopic counts, substrate-induced respiration (SIR) and adenosine triphosphate (ATP) for calculation of mass conversion factors. Conversion factors reported in the literature for agricultural soils where biomass was determined by ATP or SIR ranged from 49 to 419 nmol phospholipid-P $\mathrm{mg}^{-1}$ biomass C (Hill et al., 1993).

\subsection{Sod discrimination}

Not only does the amount of microbial biomass developed under wheat-fallow cropping differ from that of native sod, but also the composition of that biomass has changed considerably based on analysis of FAME profiles. Both cluster and discriminant analyses of PL- and EL-FAMEs clearly separated native sod plots from wheat-fallow plots. Within the EL-FAMEs

Table 4

Select mean FAME ratios in PL-FAMEs and EL-FAMEs extracted from soils in native sod or cropped to wheat or in fallow under differing tillage management

\begin{tabular}{|c|c|c|c|c|c|}
\hline \multirow[t]{2}{*}{ Tillage \& crop cycle } & \multicolumn{2}{|c|}{$\mathrm{C} 16: 1(\operatorname{cis} 11) / \mathrm{C} 16: 0$} & \multicolumn{2}{|c|}{$\mathrm{C} 18: 2(\operatorname{cis} 9,12) / \mathrm{C} 16: 0$} & \multirow{2}{*}{$\frac{c y C 19: 0(11,12) / \mathrm{C} 18: 1(c i s 11)}{\text { PL-FAMEs }}$} \\
\hline & PL-FAMEs & EL-FAMEs & PL-FAMEs & EL-FAMEs & \\
\hline \multicolumn{6}{|l|}{ Cropped } \\
\hline Plow & $0.341^{\mathrm{a}} \mathrm{a}$ & $0.271 \mathrm{a}$ & $0.362 \mathrm{a}$ & $0.543 \mathrm{a}$ & $0.586 \mathrm{ab}$ \\
\hline Sub-till & $0.345 \mathrm{a}$ & $0.430 \mathrm{~b}$ & $0.333 \mathrm{a}$ & $0.520 \mathrm{a}$ & $0.517 \mathrm{a}$ \\
\hline No-till & $0.342 \mathrm{a}$ & $0.763 \mathrm{c}$ & $0.348 \mathrm{a}$ & $0.472 \mathrm{a}$ & $0.580 \mathrm{ab}$ \\
\hline Sod & $0.384 \mathrm{~b}$ & $3.49 \mathrm{~d}$ & $0.468 \mathrm{a}$ & $0.500 \mathrm{a}$ & $0.723 \mathrm{bc}$ \\
\hline \multicolumn{6}{|l|}{ Fallow } \\
\hline Plow & $0.292 \mathrm{a}$ & $0.272 \mathrm{a}$ & $0.218 \mathrm{a}$ & $0.433 \mathrm{a}$ & $0.836 \mathrm{c}$ \\
\hline Sub-till & $0.273 \mathrm{a}$ & $0.351 \mathrm{ab}$ & $0.358 \mathrm{ab}$ & $0.524 \mathrm{ab}$ & $0.673 \mathrm{~b}$ \\
\hline No-till & $0.309 \mathrm{ab}$ & $0.391 \mathrm{~b}$ & $0.451 \mathrm{ab}$ & $0.628 \mathrm{~b}$ & $0.643 \mathrm{ab}$ \\
\hline Sod & $0.362 \mathrm{~b}$ & $3.51 \mathrm{c}$ & $0.487 \mathrm{~b}$ & $0.616 \mathrm{~b}$ & $0.712 \mathrm{bc}$ \\
\hline
\end{tabular}

\footnotetext{
a Treatment means ( $n=3 ; n=2$ for fallow plow PL-FAMEs) within crop cycle followed by the same letter do not differ significantly at $P<0.05$ by Tukey's HSD Test.
} 
this separation was largely driven by high amounts in the sod plots of a single FAME, C16:1(cis11), originating from the acetone elulate during silica gel fractionation (data not shown). Silica gel fractionation separates lipids into three basic classes based on polarity: neutral lipids, glycolipids and phospholipids (Kates, 1986). Thus, C16:1(cis11) of the EL-FAMEs is probably ester-linked to a glycolipid or another complex lipid, which elutes from silica gel with acetone. The prevalence of eukaryotic organisms in undisturbed systems is supported by higher ratios of C20:4(5,8,11,14) in sod compared to cultivated systems.

\subsection{Wheat-fallow discrimination}

In the Central Great Plains, fallow management is used to increase soil water storage for the succeeding crop although, even under the best conditions, fallow water storage efficiencies rarely exceed 35\% (Farahani et al., 1998; Fenster and Peterson, 1979; Peterson et al., 1996). Leaving cropland fallow, however, has several negative consequences for sustainable crop production, carbon sequestration and preservation of soil quality (Bowman et al., 1999; Farahani et al., 1998; Peterson et al., 1996, 1998; Wienhold and Halvorson, 1998).

The ability of FAMEs to discriminate among tillage treatments was expressed most strongly during fallow. During the wheat cycle the soil microbial community would be dominated by those organisms responding to inputs from the wheat leading to closely grouped FAME profiles irrespective of tillage. During fallow, the physicochemical environment that is largely dictated by tillage management would control residue decomposition rates and microbial succession patterns. PL-FAMEs sensitive to tillage during fallow included C15:0, $a \mathrm{C} 15: 0$ and $\mathrm{C} 16: 1(c i s 9)$ which decreased under plow. Tillage discrimination based on EL-FAMEs was evident for C16:1(cis11) during both cropping cycles, while C18:2(cis 9,12) declined with increasing tillage intensity during fallow (Table 4). The eukaryotic biomarker C20:4(5,8,11,14) was below detection in ELFAMEs during fallow.

Formation of cyclopropane fatty acids from their monoenoic precursors within the plasma membrane of bacteria is associated with cell stasis (Grogan and Cronan, 1997) and/or stress (Grogan and Cronan, 1997; Kieft et al., 1994, 1997; Petersen and Klug, 1994). Within PL-FAMEs, mean ratios of $c y \mathrm{C} 19: 0(11,12)$ to its monenoic precursor $\mathrm{C} 18: 1$ (cis11) were greatest in FP and sod and least after wheat harvest indicating a greater proportion of the bacterial biomass in FP and sod was in stasis (Table 4; Grogan and Cronan, 1997). Although \%WFPS was not optimum in any of the plots at sampling, bioavailability of carbon would have been most restricted in FP.

The relationship of crop and tillage management to fungal biomass is unclear from analysis of the fungal biomarker C18:2(cis9,12) (Table 4). C18:2(cis9,12) is closely correlated with fungal biomass in soils as measured by the fungal sterol ergosterol (Frostegård and Bååth, 1996), and ${ }^{13} \mathrm{C}$ incorporation into soil phospholipids (Arao, 1999). There was no significant difference in the relative abundance of this FAME in the phospholipid fraction of cropped or fallowed soils nor in sod. At this same site, Frey et al. (1999) reported significant declines in fungal biomass (calculated from fungal hyphal lengths) with tillage in the 0 $5 \mathrm{~cm}$ depth. Although the proportion of total biomass represented by fungal structures containing intact phospholipid membranes does not likely differ among the cropping systems at the time the soils were sampled, remnant hyphae devoid of cytoplasm accumulated under NT and contributed to greater aggregate stability (Cambardella and Elliott, 1993; Frey et al., 1999). Declines with tillage were observed for C18:2(cis9,12) in the EL-FAMEs during fallow supporting the existence of other eukaryotic lipid containing structures sensitive to tillage.

\subsection{Significance of C16:1(cis11)}

Recent studies have noted the sensitivity of C16:1(cis11) within the PL-FAMEs of forest soils to metal contamination (Bååth et al., 1992) and $\mathrm{pH}$ (Frostegård et al., 1993). This FAME has also been cited as a biomarker for arbuscular mycorrhizal (AM) fungi in soils and colonized roots (Olsson et al., 1995). Within Glomus species, this marker is present in two lipid classes: neutral lipids, important as storage forms (spores and vesicles) and phospholipids, from fungal hyphae (Olsson et al., 1995; Sancholle and Dalpé, 1993). This FAME has also been found in the glycolipid fraction of AM fungi (Jabaji-Hare et al., 1984).

The probable origin of C16:1(cis11) from AM fungi is supported by its prevalence in less disturbed systems, i.e. sod and WNT plots, with lowest amounts in WP and FP systems (Table 4). The majority of the AM fungal biomass in soil is located outside the roots as extraradical mycelium and spores (Olsson et al., 1997). Tillage is known to decrease hyphal lengths of all fungi, including AM fungi, in soils (Beare, 1997; Kabir et al., 1999; Miller et al., 1995; O'Halloran et al., 1986; Wardle, 1995). Furthermore, a sustained input of carbon seems to be required for preservation of $\mathrm{AM}$ fungi in soils, as the relative abundance C16:1(cis11) within the EL-FAMEs declined significantly during fallow. In contrast, only modest declines in C16:1(cis11) from PL-FAMEs were observed during fallow, and tillage was not a factor. This supports the 
data of Olsson et al. (1995) where, upon soil storage, significant declines were observed in C16:1(cis11) from the neutral lipid fraction, while declines in the phospholipid fraction were minimal. Thus, removal of the plant forces the fungus to rely on its stored carbon resources or these resources become fodder for the soil's heterotrophic community. Additional studies are underway to verify the importance of AM fungi to this system.

A second group of organisms known to contain C16:1(cis11) in significant amounts are members of the Cytophaga-Flexibacter group (Nichols et al., 1986b). Walker (1969) was the first to demonstrate C16:1(cis11) as the dominant fatty acid in phosphatidyl ethanolamine extracted from Cytophaga hutchinso$n i i$, a cellulose degrading microorganism. In Walker's study, C16:1(cis11) was not recovered from the glycolytic fraction; hence, cellulolytic cytophagas are probably not the primary source of C16:1(cis 11$)$ in the ELFAMEs of this study.

\subsection{Treatment discrimination by $P L-F A M E s$ and $E L$ - FAMEs}

Currently, PL-FAMEs are preferred for determining microbial community structure of soils based on the assumption that these lipids are found only in living cells, turnover rapidly upon cell death and are not components of storage lipids (White et al., 1979). In this study, however, useful information was gained from EL-FAMEs regarding microbial community structure and physiological status. The prevalence of mycorrhizal fungi in sod and its sensitivity to tillage under wheat-fallow cropping was only apparent from C16:1(cis11) in EL-FAMEs. A decline in the fungal biomarker C18:2(cis 9,12) of EL-FAMEs with tillage during fallow supports previous work based on fungal hyphal lengths (Frey et al., 1999), although fungal biomass with intact cytoplasm was similar among the systems. The move towards direct extraction and saponification of EL-FAMEs from soils without the use of chloroform or silica gel chromatography has surfaced in part due to its simplicity and application to a large number of samples (Cavigelli et al., 1995).

In this study, we have demonstrated treatment discrimination by both PL-FAMEs and EL-FAMEs that were in large part complimentary. Reliance only on EL-FAMEs may lead to a loss of information about parent lipid and cellular location, as well as the potential for inclusion of storage lipids. Therefore, preliminary screening of soil samples using EL-FAMEs followed by more detailed lipid analyses may be necessary to more fully understand the ecology of a system.

\section{Acknowledgements}

This work was supported by the University of Nebraska, Lincoln and the State of Nebraska and USDA/CREES. Special thanks to Jane Clegg for GC analysis and Lisa Cooper for GC-MS identification.

\section{References}

Arao, T., 1999. In situ detection of changes in soil bacterial and fungal activities by measuring ${ }^{13} \mathrm{C}$ incorporation into soil phospholipid fatty acids from ${ }^{13} \mathrm{C}$ acetate. Soil Biology \& Biochemistry 31 , $1015-1020$

Bååth, E., Frostegård, Å., Fritze, H., 1992. Soil bacterial biomass, activity, phospholipid fatty acid pattern, and $\mathrm{pH}$ tolerance in an area polluted with alkaline dust deposition. Applied and Environmental Microbiology 58, 4026-4031.

Bååth, E., Frostegård, Å., Pennanen, T., Fritze, H., 1995. Microbial community structure and $\mathrm{pH}$ response in relation to soil organic matter quality in wood-ash fertilized, clear-cut or burned coniferous forest soils. Soil Biology \& Biochemistry 27, 229-240.

Beare, M.H., 1997. Fungal and bacterial pathways of organic matter decomposition and nitrogen mineralization in arable soils. In: Brussaard, L., Ferrera-Cerrato, R. (Eds.), Soil Ecology in Sustainable Agricultural Systems. Lewis Publishers, Boca Raton, FL, pp. 37-70

Beare, M.H., Hendrix, P.F., Coleman, D.C., 1994. Water-stable aggregates and organic matter fractions in conventional and notillage soils. Soil Science Society of America Journal 58, 777-786.

Bowman, R.A., Vigil, M.F., Nielsen, D.C., Anderson, R.L., 1999. Soil organic matter changes in intensively cropped dryland systems. Society of America Journal 63, 186-191.

Broder, M.W., Doran, J.W., Peterson, G.A., Fenster, C.R., 1984 Fallow tillage influence on spring populations of soil nitrifiers, denitrifiers, and available nitrogen. Soil Science Society of America Journal 48, 1060-1067.

Cambardella, C.A., Elliott, E.T., 1992. Particulate soil organic-matter changes across a grassland cultivation sequence. Soil Science Society of America Journal 56, 777-783.

Cambardella, C.A., Elliott, E.T., 1993. Carbon and nitrogen distribution in aggregates from cultivated and native grassland soils. Soil Science Society of America Journal 57, 1071-1076.

Cavigelli, M.A., Robertson, G.P., Klug, M.J., 1995. Fatty acid methy ester (FAME) profiles as measures of soil microbial community structure. Plant and Soil 170, 99-113.

Doran, J.W., 1980. Soil microbiological and biochemical changes associated with reduced tillage. Soil Science Society of America Journal 44, 765-771.

Doran, J.W., 1987. Microbial biomass and mineralizable nitrogen distributions in no-tillage and plowed soils. Biology and Fertility of Soils 5, 68-75.

Doran, J.W., Elliott, E.T., Paustian, K., 1998. Soil microbial activity, nitrogen cycling, and long term changes in organic carbon pools as related to fallow tillage management. Soil \& Tillage Research 49, 3-18.

Doran, J.W., Linn, D.M., 1994. Microbial ecology of conservation management systems. In: Hatfield, J.L., Stewart, B.A. (Eds.), Soil Biology: Effects on Soil Quality. Lewis Publishers, Boca Raton, FL, pp. 1-27.

Drijber, R.A., McGill, W.B., 1994. Sulfonolipids as a biomarker to monitor the population dynamics of the genera Cytophaga and Flexibacter in soil worked by the earthworm Aporrectodea turgida. Soil Biology \& Biochemistry 26, 1395-1403.

Farahani, H.J., Peterson, G.A., Westfall, D.G., Sherrod, L.A., 
Ahuja, L.R., 1998. Soil water storage in dryland cropping systems: the significance of cropping intensification. Soil Science Society of America Journal 62, 984-991.

Fenster, C.R., Peterson, G.A., 1979. Effects of no-tillage fallow as compared to conventional tillage in a wheat-fallow system. Nebraska Agriculture Experiment Station Research Bulletin No. 289.

Follett, R.F., Paul, E.A., Leavitt, S.W., Halvorson, A.D., Lyon, D., Peterson, G.A., 1997. Carbon isotope ratios of Great Plains soils in wheat-fallow systems. Soil Science Society of America Journal 61, 1068-1077.

Frey, S.D., Elliott, E.T., Paustian, K., 1999. Bacterial and fungal abundance and biomass in conventional and no-tillage agroecosystems along two climatic gradients. Soil Biology \& Biochemistry 31, 573-585.

Frostegård, Å, Bååth, E., 1996. The use of phospholipid fatty acid analysis to estimate bacterial and fungal biomass in soil. Biology and Fertility of Soils 22, 59-65.

Frostegård, Å., Bååth, E., Tunlid, A., 1993. Shifts in the structure of soil microbial communities in limed forests as revealed by phospholipid fatty acid analysis. Soil Biology \& Biochemistry 25, 723730.

Grogan, D.W., Cronan Jr., J.E., 1997. Cyclopropane ring formation in membrane lipids of bacteria. Microbiology and Molecular Biology Reviews 61, 429-441.

Hill, T.C.J., McPherson, E.F., Harris, J.A., Birch, P., 1993. Microbial biomass estimated by phospholipid phosphate in soils with diverse microbial communities. Soil Biology \& Biochemistry 25, 1779-1786.

Huggins, D.R., Buyanovsky, G.A., Wagner, G.H., Brown, J.R., Darmody, R.G., Peck, T.R., Lesoing, G.W., Vanotti, M.B., Bundy, L.G., 1998. Soil organic C in the tallgrass prairie-derived region of the corn belt: effect of long-term crop management. Soil \& Tillage Research 47, 219-234.

Jabaji-Hare, S., Deschene, A., Kendrick, B., 1984. Lipid content and composition of vesicles of a vesicular-arbuscular mycorrhizal fungus. Mycologia 76, 1024-1030.

Kabir, Z., O'Halloran, I.P., Hamel, C., 1999. Combined effects of soil disturbance and fallowing on plant and fungal components of mycorrhizal corn (Zea mays L.). Soil Biology \& Biochemistry 31, 307-314.

Kates, M., 1986. Techniques of lipidology: isolation, analysis and identification of lipids. In: Burdon, R.H., van Kippenberg, P.H. (Eds.), Laboratory Techniques in Biochemistry and Molecular Biology, vol. 3, Part 2. Elsevier, NY.

Kessavalou, A., Mosier, A.R., Doran, J.W., Drijber, R.A., Lyon, D.J., Heinemeyer, O., 1998. Fluxes of carbon dioxide, nitrous oxide, and methane in grass sod and winter wheat-fallow tillage management. Journal of Environmental Quality 27, 1094-1104.

Kieft, T.L., Ringelberg, D.B., White, D.C., 1994. Changes in esterlinked phospholipid fatty acid profiles of subsurface bacteria during starvation and dessication in a porous medium. Applied and Environmental Microbiology 60, 3292-3299.

Kieft, T.L., Wilch, E., O'Connor, K., Ringelberg, D.B., White, D.C., 1997. Survival and phospholipid fatty acid profiles of surface and subsurface bacteria in natural sediment microcosms. Applied and Environmental Microbiology 63, 1531-1542.

Lyon, D.J., Stroup, W.W., Brown, R.E., 1998. Crop production and soil water storage in long-term winter wheat-fallow tillage experiments. Soil \& Tillage Research 49, 19-28.

Mielke, L.N., Wilhelm, W.W., 1998. Comparisons of soil physical characteristics in long-term tillage winter wheat-fallow tillage experiments. Soil and Tillage Research 49, 29-35.

Miller, M.H., McGonigle, T.P., Addy, H.D., 1995. Functional ecology of vesicular arbuscular mycorrhizas as influenced by phosphate fertilization and tillage in an agricultural ecosystem. Critical Reviews in Biotechnology 15, 241-255.
Nebraska Agricultural Statistics Service, 1996. Nebraska agricultural statistics, 1995-1996. Lincoln, NE, 152 pp.

Nichols, P.D., Guckert, J.B., White, D.C., 1986a. Determination of monounsaturated fatty acid double-bond position and geometry for microbial monocultures and complex consortia by capillary GC-MS of their dimethyl disulphide adducts. Journal of Microbiological Methods 5, 49-55.

Nichols, P., Stulp, B.K., Jones, J.G., White, D.C., 1986b. Comparison of fatty acid content and DNA homology of the filamentous gliding bacteria Vitreoscilla, Flexibacter, Filibacter. Archives of Microbiology 146, 1-6.

O'Halloran, L.P., Miller, M.H., Arnold, G., 1986. Absorption of P by corn (Zea mays L.) as influenced by soil disturbance. Canadian Journal of Soil Science 66, 287-302.

O'Halloran, L.P., Stewart, J.W.B., De Jong, E., 1987. Changes in P forms and availability as influenced by management practices. Plant and Soil 100, 113-126.

Olsson, P.A., Bååth, E., Jakobsen, I., Söderström, B., 1995. The use of phospholipid and neutral lipid fatty acids to estimate biomass of arbuscular mycorrhizal fungi in soil. Mycological Research 99, 623-629.

Olsson, P.A., Bååth, E., Jakobsen, I., 1997. Phosphorus effects on the mycelium and storage structures of an arbuscular mycorrhizal fungus as studied by analysis of fatty acid signatures. Applied and Environmental Microbiology 63, 3531-3538.

Paul, E.A., Clark, F.E., 1989. Soil Microbiology and Biochemistry. Academic Press, San Diego CA, p. 273.

Paustian, K., Robertson, G.P., Elliott, E.T., 1995. Management impacts on carbon storage and gas fluxes $\left(\mathrm{CO}_{2}, \mathrm{CH}_{4}\right)$ in mid-latitude cropland. In: Lal, R., Kimbel, J., Levine, E., Stewart, B.A. (Eds.), Soil Management and Greenhouse. Lewis Publishers, Boca Raton, FL, pp. 69-83.

Petersen, S.O., Debosza, K., Schjønning, P., Christensen, B.T., Elmholt, S., 1997. Phospholipid fatty acid profiles and C availability in wet-stable macro-aggregates from conventionally and organically farmed soils. Geoderma 78, 181-196.

Petersen, S.O., Klug, M.J., 1994. Effects of sieving, storage, and incubation temperature on the phospholipid fatty acid profile of a soil microbial community. Applied and Environmental Microbiology 60, 2421-2430.

Peterson, G.A., Halvorson, A.D., Havlin, J.L., Jones, O.R., Lyon, D.J., Tanaka, D.L., 1998. Reduced tillage and increasing cropping intensity in the Great Plains conserves soil C. Soil \& Tillage Research 47, 207-218.

Peterson, G.A., Schlegel, A.J., Tanaka, D.L., Jones, O.R., 1996. Precipitation use efficiency as affected by cropping and tillage systems. Journal of Production Agriculture 9, 180-186.

Reichardt, W., Mascariña, G., Padre, B., Doll, J., 1997. Microbial communities in continuously cropped, irrigated rice fields. Applied and Environmental Microbiology 63, 233-238.

Sancholle, M., Dalpé, Y., 1993. Taxonomic relevance of fatty acids of arbuscular mycorrhizal fungi and related species. Mycotaxonomy 49, 187-193.

SAS Institute Inc., 1989. SAS/STAT ${ }^{\circledR}$ User's Guide, Version 6, 4th ed., vol. 1 \& 2. SAS Institute Inc., Cary, NC.

Statistica for Windows, 1995. StatSoft, Inc., Tulsa, OK.

Walker, R.W., 1969. Cis-11-hexadecenoic acid from Cytophaga hutchinsonii lipids. Lipids 4, 15-18.

Wander, M.M., Hedrick, D.S., Kaufman, D., Traina, S.J., Stinner, B.R., Kehrmeyer, S.R., White, D.C., 1995. The functional significance of the microbial biomass in organic and conventionally managed soils. Plant and Soil 170, 87-97.

Wardle, D.A., 1995. Impacts of disturbance on detritus food webs in agro-ecosystems of contrasting tillage an weed management practices. Advances in Ecological Research 26, 105-185.

White, D.C., Davis, W.M., Nickels, J.S., King, J.D., Bobbie, R.J., 
1979. Determination of the sedimentary microbial biomass by extractable lipid phosphate. Oecologia 40, 51-62.

Wienhold, B.J., Halvorson, A.D., 1998. Cropping system influences on several soil quality attributes in the northern Great Plains. Journal of Soil and Water Conservation 53, 254-258.

Yu, Q.T., Liu, B.N., Zhang, J.Y., Huang, Z.H., 1989. Location of double bonds in fatty acids of fish oil and rat testis lipids. Gas chromatography-mass spectrometry of the oxazoline derivatives. Lipids 24, 79-83.
Zelles, L., Bai, Q.Y., Beck, T., Beese, F., 1992. Signature fatty acids in phospholipids and lipopolysaccharides as indicators of microbial biomass and community structure in agricultural soils. Soil Biology \& Biochemistry 24, 317-323.

Zogg, G.P., Zak, D.R., Ringelberg, D.B., MacDonald, N.W., Pregitzer, K.S., White, D.C., 1997. Compositional and functional shifts in microbial communities due to soil warming. Soil Science Society of America Journal 61, 475-481. 